\author{
JOLANTA BLICHARZ \\ ORCID: 0000-0002-4581-8629 \\ Uniwersytet Wrocławski \\ jolanta.blicharz@uwr.edu.pl
}

\title{
Niepomijalność podmiotowości człowieka i niepomijalność misji administracji publicznej w służbie dobru wspólnemu (dobru osobowemu)
}

\begin{abstract}
Abstrakt: Istnieją co najmniej trzy poważne argumenty na rzecz tezy, że koncepcja dobra wspólnego i koncepcja godności jako wymiaru podmiotowości człowieka wzajemnie się warunkują i nie mogą być rozwijane niezależnie od siebie. Po pierwsze, dobro wspólne zasadza się w uznaniu godności człowieka; po wtóre, udaremnienie realizacji dobra wspólnego przez prawo i państwo jest podważeniem godności ludzkiej osoby; po trzecie, położenie akcentu na podmiotowość człowieka (jego godność) oraz przyporządkowanie instytucji społecznych dobru wspólnemu pozwala na odróżnienie tego, co jest celem działania państwa, a co środkiem do niego prowadzącym.
\end{abstract}

Słowa kluczowe: godność człowieka, administracja publiczna, państwo, dobro wspólne.

\section{Słów parę o podmiotowości człowieka}

Pomijając historyczne fluktuacje znaczeniowe pojęcia „podmiotowość człowieka" oraz wszelkie rodzaje jego błędnego użycia (na przykład koncepcja kolektywistycznego pojmowania człowieka), możemy powiedzieć, że termin ten, tak jak jest zwykle rozumiany, zawiera trzy składniki.

Po pierwsze, mówiąc o podmiotowości człowieka, myślimy o materialnym i duchowym wymiarze jego natury. Rodzi to zasadniczą konsekwencję uznania 
nadrzędnej wartości osoby ludzkiej wobec świata rzeczy oraz struktur ekonomiczno-społecznych i politycznych ${ }^{1}$.

Po wtóre, wymiarem podmiotowości człowieka jest jego godność jako wartość niezbywalna i niepowtarzalna (od strony ontologicznej). Ten wątek rozumowania znalazł się również w wielu nurtach i szkołach myśli personalistycznej, nabywając bardziej uniwersalnego charakteru, z którym wiążą się między innymi takie elementy, jak troska o godność osoby ludzkiej, o prawa i wartości jej najbliższe czy wyczulenie na osobistą i społeczną wolność 2 .

Po trzecie, w związku z tym, że życie osobowe człowieka realizuje się zawsze w konkretnych warunkach, właściwą dla człowieka postawą jest postawa zaangażowania. Z koncepcji personalizmu jako postawy „życiowego zaangażowania” wynika, że „terenem i zakresem tego zaangażowania jest bowiem prywatne i publiczne, społeczne, polityczne i ogólne życie człowieka jako osoby mającej obowiązek coraz głębszego uświadamiania sobie swego historycznego powołania"3. W realizowaniu tego powołania człowiek nie może stawać się niczyim narzędziem i musi mieć zapewniony taki dobór środków działania, aby mógł się doskonalić zarówno w sferze życia wewnętrznego, jak i w ścisłym powiązaniu z życiem społecznym ${ }^{4}$. Z tego właśnie wynika podstawa stanowiska personalistycznego w odniesieniu do życia społecznego - podporządkowanie struktur i urządzeń zbiorowych służbie rozwojowi osobowemu człowieka w społeczeństwie.

W tym miejscu warto zaznaczyć, że w poglądach niektórych przedstawicieli personalistycznego nurtu myślowego (na przykład E. Mouniera) występuje wyraźne rozróżnienie jednostki i osoby. Jednostka oznacza tu wyodrębnienie od gatunku i w gatunku - w tym znaczeniu, że dzięki jednostkom gatunek ludzki różni się od wszelkich innych, a zarazem jest zbiorem jednostek przynależnych do gatunku ludzkiego ${ }^{5}$. Można powiedzieć, że jednostka tkwi w materii i naturze, natomiast osoba to świat absolutny dla siebie, etyka, prawa ${ }^{6}$. W przeciwieństwie do jednostki osoba określa człowieka jako istotę rozumną, wolną, autonomiczną, niezniszczalną i decydującą o własnym losie ${ }^{7}$. Innymi słowy osoba jest obecnością, a nie bytem - dlatego też zdefiniowanie osoby jest niemożliwe. Co więcej, nie jest ona jednym z wielu poznawanych przedmiotów, ale - jak powiada Mounier — jest jedyną rzeczywistością, którą znamy i którą jednocześnie od

1 Por. R. Czekalski, Personalistyczna pedagogika wychowawcza Jana Pawła II, „Warszawskie Studia Teologiczne” 21, 2008, s. 186.

2 Por. R. Kozłowski., Wokót problemu osoby. Definicje osoby w polskim personalizmie chrześcijańskim, „Stupskie Studia Filozoficzne” 2005, nr 5, s. 79.

3 J. Legowicz, Zarys historii filozofii, Warszawa 1980, s. 468.

4 Ibidem.

5 Ibidem, s. 469.

${ }^{6}$ G. Barth, Pojęcie i rozwój personalizmu, http://hosting0800050.az.pl/personalizm/?p=142 (dostęp: 3.01.2019).

7 J. Legowicz, op. cit., s. 470. 
wewnątrz tworzymy ${ }^{8}$. Jakkolwiek nauki szczegółowe pomagają w zrozumieniu pewnych pojedynczych aspektów osoby, nie wyjaśniają jednak całości jej tajemnicy, tak jak ,tysiąc zestawionych razem fotografii nie stanowi człowieka, który idzie, myśli i chce"".

Trzeba też zaznaczyć, że wymiarem podmiotowości człowieka jest jego godność. Aby rzucić nieco światła na współczesne dociekania na temat godności człowieka, należy koniecznie zwrócić uwagę na to, iż stanowi ona wzorcową zasadę, podstawę, w oparciu na której można by ustanawiać reguły, zasady i standardy prawa. Dla interpretacji tego, co należy rozumieć jako godność człowieka, zasadniczego znaczenia nabiera art. 30 Konstytucji RP, zgodnie z którym: „Przyrodzona i niezbywalna godność człowieka stanowi źródło wolności i praw człowieka i obywatela. Jest ona nienaruszalna, a jej poszanowanie i ochrona jest obowiązkiem władz publicznych”. Pojęcie „przyrodzonej” godności człowieka oznacza, że godność człowieka jest czymś swoiście własnym, należnym każdemu człowiekowi, bo danym mu wraz z byciem sobą. Ustawa zasadnicza słusznie stwierdza, że godność jest niezbywalna, co znaczy nie tylko, że nie można jej nikomu odstąpić, ale że jest ona ściśle związana z człowieczeństwem. Godność człowieka jest dana jako rzeczywistość niezbywalna, domagająca się przyjęcia i uznania. Nienaruszalność godności oznacza, że nie można odebrać człowiekowi prawa do szacunku. Pojęcie „poszanowania” godności oznacza obiektywne prawo do szacunku oraz subiektywne respektowanie tego prawa do szacunku ${ }^{10}$. $\mathrm{Z}$ tego, że prawo do szacunku jest nienaruszalne, wynika natomiast, że władze publiczne są zobowiązane do poszanowania tego prawa, a tam, gdzie byłoby ono zagrożone lub lekceważone, do jego ochrony ${ }^{11}$.

8 Por. A. Drabarek, Dlaczego personalizm nie jest i nie może stać się filozofia niedzielnego popotudnia, „Studia Philosophiae Christianae” 48, 2012, nr 4, s. 101.

9 M. Apiecionek, Idea personalizmu Emmanuela Mouniera, „Filozofia Chrześcijańska” 13, 2016, s. 153.

10 Ibidem, s. 27.

11 Jak zauważa K. Complak, „godność osoby ludzkiej dotyczy ogółu konstytucyjnych przepisów wyznaczających położenie człowieka oraz obywatela w państwie”, jak również, że „omawiana kategoria wykracza jednak poza dogmatykę konstytucji”, wskazując jednocześnie wstęp Konstytucji, w którym wzywa się wszystkich, aby stosując ją, czynili to, dbając o zachowanie przyrodzonej godności człowieka, mając na myśli ogół władz publicznych (w szczególności organów wymiaru sprawiedliwości) - idem, Uwagi o godności człowieka oraz jej ochrona w świetle nowej konstytu$c j i$, „Przegląd Sejmowy” 1998, nr 5 (28), s. 45. Autor dalej wskazuje na chrześcijański, ale i świecki punkt widzenia pojęcia ,godności człowieka”. Mianowicie w świetle nauki Kościoła katolickiego „godność osoby ludzkiej ma podstawę w stworzeniu jej na obraz i podobieństwo Boże [...]; wypełnia się ona w powołaniu Boskiego szczęścia [...]. Jest właściwe istocie ludzkiej, że w sposób dobrowolny dąży do tego wypełnienia $[\ldots]$. Osoba ludzka przez swoje świadome czyny [...] dostosowuje się lub nie do dobra obiecanego przez Boga i potwierdzonego przez sumienie moralne [...]. Ludzie kształtują samych siebie i wzrastają wewnętrznie; całe swoje życie zmysłowe i duchowe czynią przedmiotem swojego wzrostu [...]. Jeśli chodzi o świeckie pojęcie godności, to również akcentuje odmienność jakościową człowieka, w szczególności wyższość osoby ludzkiej nad materią 
Dokonując koniecznego uogólnienia, można powiedzieć, że norma konstytucyjna o nienaruszalności godności człowieka oraz nakaz jej poszanowania i ochrony wywodzą się i dają się wyprowadzić z bytu człowieka. Innymi słowy godność człowieka nie wynika z ustanowienia jej przez powołane do tego organy, albowiem w przypadku państw lub społeczeństw, w których brakuje odpowiednich przepisów konstytucji o ochronie godności człowieka, można by ją lekceważyć, a prawa człowieka byłyby naruszane lub ograniczane. Godność człowieka jako odkryta rzeczywistość niezbywalna polega więc na uznaniu, a następnie sformułowaniu w postaci przepisów prawa.

\section{Jakie jest przesłanie administracji publicznej? I dlaczego jest tak aktualne?}

Aktualność administracji publicznej nie polega na tym, że wszyscy dziś myślą o niej, lecz właśnie na tym, że już zapomnieli, co tak naprawdę jest jej misją i celem. Warto odwołać się w tym względzie do definicji J. Bocia, zgodnie z którą administracją publiczną jest przejęte przez państwo i realizowane przez jego zawisłe organy, a także organy samorządu terytorialnego, zaspokajanie zbiorowych i indywidualnych potrzeb obywateli wynikających ze współżycia ludzi w społecznościach ${ }^{12}$. Wskazany autor w uzasadnieniu swojej definicji podaje: „Wydaje się, że proponowanemu tu określeniu można przypisać istotne funkcje. Przede wszystkim przywraca ono właściwy wymiar państwowej i samorządowej dbałości o dobro obywateli, wskazując zarazem na służebną rolę administracji”"13. Ważność tego przekonania zasadza się w uznaniu dbałości o dobro obywateli (choć pełniej należałoby powiedzieć człowieka, który przecież nie musi być obywatelem), dlatego że żyje on w społeczności ${ }^{14}$.

Warto tu przede wszystkim odnotować, że właśnie dobro wspólne - tak zapomniana dzisiaj kategoria, a jednocześnie tak mocno podkreślana w społecznej nauce Kościoła, traktowana jako powinność i prawo człowieka ${ }^{15}$ — staje się

martwą oraz w ogóle nad całym światem żywym, niemającym świadomości, rozumu czy swobody działania" - ibidem, s. $41 \mathrm{n}$.

12 J. Boć, Prawo administracyjne, Wrocław 2004, s. 16.

13 Ibidem, s. 17.

14 S. Fundowicz, Człowiek i administracja publiczna, [w:] Prawość i godność. Księga pamiątkowa w 70. rocznicę urodzin Profesora Wojciecha Laczkowskiego, red. S. Fundowicz, F. Rymarz, A. Gomułowicz, Lublin 2003, s. 106-107.

15 Tak na przykład w encyklice Populorum progresso Pawła VI i Laborem exercens Jana Pawła II. Dla Jana Pawła II źródłem i wyznacznikiem bonum commune jest dobro osoby ludzkiej, tym samym ludzka godność staje się kryterium dobra wspólnego. Jeśli państwo przestanie służyć dobru wspólnemu, rozumianemu jako możliwie najszersza realizacja praw człowieka, może dojść 
kolejnym przełomem w myśleniu o relacjach podmiotowość człowieka-administracja publiczna. Trzeba też zaznaczyć, że administracja, realizując funkcje państwa, w konsekwencji polega na bezpośrednim realizowaniu dobra wspólnego, które odgrywa rolę pojęcia-narzędzia, wskazując istnienie skonkretyzowanych wartości oraz celów w obowiązujących regulacjach prawnych ${ }^{16}$. Z treści art. 1 Konstytucji, który określa Rzeczpospolitą Polską jako dobro wspólne obywateli, wynikają zobowiązania państwa wobec nich. Podkreśla się przede wszystkim, że zasada ta jest i powinna być interpretowana jako stojąca na straży praw jednostek. Od realizacji tych praw zależy przecież pomyślność całej wspólnoty ${ }^{17}$. Dobro wspólne nie jest jednak sumą dóbr indywidualnych ani nie oznacza zbiorowej potrzeby ${ }^{18}$. Podążając za poglądem wyrażonym w literaturze, można uznać, iż ,jest ono wynikiem skoordynowanych działań wszystkich (lub większości) członków zbiorowości, jednoczących się we wspólnym wysiłku w celu urzeczywistnienia większości ogółu"19. Można nawet postąpić o krok dalej i stwierdzić, że dążenie do dobra wspólnego jako najważniejszego prawa społecznego jest punktem wyjścia osiągnięcia sprawiedliwości ${ }^{20}$.

Obok pojęcia dobra wspólnego (powszechnego) równolegle występuje termin ,interes publiczny”. Związek ich występowania w praktyce jest dosyć bliski, w związku z czym pojawiają się trudności w pojęciowym, wyraźnym ich rozdzieleniu. Niejednokrotnie też dobro wspólne (powszechne) utożsamiane jest z interesem publicznym. Dobro wspólne z punktu widzenia moralnego i religijnego bez wątpienia stanowi wartość wyższą od interesu publicznego - należy ono do sfery „być” ${ }^{21}$. Dobro wspólne jako wartość nie tylko jest jakimś stałym elementem rzeczywistości, ale jednocześnie ma charakter powszechny, to znaczy dotyczy każdego człowieka. Zakłada ono wyobrażenie o człowieku oraz o jego stosunku do społeczeństwa. Trochę upraszczając, możemy stwierdzić że człowiek w wymiarze statycznym jest istotą otwartą na dobro wspólne (to jest mającą intuicję co do tej wartości), w wymiarze zaś dynamicznym jest istotą, której bycie jest byciem ku dobru (znaczy to, że kierunek życia i jego sens wyznaczany jest przez tę wartość).

W przeciwieństwie do interesu, który jest subiektywny i zmienny oraz należy do sfery „mieć” 22 , dobro wspólne jako wartość nie potrzebuje żadnego uzasadnie-

do rozwoju totalitaryzmów; zob. P. de Laubier, Myśl społeczna Kościoła katolickiego od Leona XIII do Jana Pawła II, Warszawa 1988, s. 138.

16 Zob. S.L. Stadniczenko, Etos pracowników zawodów administracji publicznej, [w:] Między tradycją a przyszłościa w nauce prawa administracyjnego. Księga jubileuszowa dedykowana Profesorowi Janowi Bociowi, red. J. Supernat, Wrocław 2009, s. 644.

17 Zob. B. Banaszak, Zasady ustroju a prawa jednostki, „Rzeczpospolita” 14-15.06.1995.

18 K. Complak, Normy pierwszego rozdziału Konstytucji RP, Wrocław 2007, s. 48.

19 Ibidem.

20 Ibidem.

21 Ibidem, s. 49.

22 Ibidem. 
nia swojego istnienia. Przede wszystkim wyjaśnia ono aktywność aksjologiczną człowieka. Można z tej perspektywy zaryzykować twierdzenie, że dobro to rodzaj wewnętrznego wzorca, w którym państwo ma swoją genezę, a przyczyną celową jest stworzenie warunków do jego rozwijania.

Z kolei jeśli chodzi o interes publiczny, to jego znaczenie opisowe związane jest $\mathrm{z}$ kontekstem społecznym i politycznym ${ }^{23}$. Interes publiczny jest uwarunkowany czasem, miejscem i wszelkiego rodzaju okolicznościami faktycznymi. Dodajmy, że rozpowszechnienie przez rewolucję francuską kategorii interesu publicznego, czy później w tak zwanych państwach socjalistycznych interesu społecznego ${ }^{24}$, spowodowało nie tylko utożsamianie tego ostatniego z interesem państwa, ale też przyczyniło się do całkowitego zapomnienia nauki o dobru wspólnym. Współczesne rozumienie interesu publicznego znajduje przede wszystkim wyraz w obowiązującym prawie. Jest to pojęcie-narzędzie służące opisaniu relacji między położeniem jednostki (obywatela) a działalnością administracji publicznej ${ }^{25}$, szczególnie gdy chodzi o udowodnienie, iż w interesie publicznym leży ograniczenie uprawnień indywidualnych. Na temat relacji między interesem publicznym a dobrem wspólnym w prawie administracyjnym można powiedzieć, że interes publiczny jest składnikiem aktu administracyjnego (nie wykracza poza prawo administracyjne), natomiast dobro wspólne jest (lub powinno być) atrybutem każdej normy prawnej ${ }^{26}$.

W istocie można bowiem przyznać, że uznając „dobro wspólne” i jego konsekwencje aksjologiczne, tym samym dokonaliśmy wyboru etycznego na rzecz pewnej wizji państwa i jego instytucji w jego realizacji. Trzeba jednocześnie pamiętać, że siła władzy państwowej zależy dziś od tego, czy rządzący potrafią rozpoznać, co należy do zakresu ich obowiązków w realizacji dobra wspólnego, w którego obszarze niewątpliwie znajduje się ochrona przed depersonalizacją współczesnego człowieka (pozbawienia go osobowej podmiotowości).

\section{Zależność między koncepcją dobra wspólnego a koncepcją godności jako wymiaru podmiotowości człowieka}

Choć ustaliliśmy już, że pojęcie osoby kojarzy się z godnością człowieka oraz że istotnym znakiem cywilizacji, która zasługuje na to imię, jest zrozumienie

${ }^{23}$ Zob. J. Blicharz, Kategoria interesu publicznego jako przedmiot działania administracji publicznej, ,Przegląd Prawa i Administracji” 40, 2004, s. 39.

${ }^{24}$ K. Complak, Normy..., s. 47.

25 Zob. H. Izdebski, M. Kulesza, Administracja publiczna, Warszawa 2004, s. 97.

${ }^{26}$ Zob. J. Blicharz, L. Zacharko, Globalizm a personalizm wobec administracji publicznej. Studium prawno-administracyjne, Wrocław 2019, s. 107 n. 
i szacunek dla godności osoby ludzkiej — jak pisał J. Maritain ${ }^{27}$ — pozostaje jeszcze kwestia zależności między koncepcją dobra wspólnego jako podstawowej racji istnienia władzy publicznej i administracji, która jej służy, wykonując konkretne zadania, a podmiotowością człowieka (jego godnością).

Istnieją co najmniej trzy poważne argumenty na rzecz tezy, że koncepcja dobra wspólnego i koncepcja godności jako wymiaru podmiotowości człowieka wzajemnie się warunkują i nie mogą być rozwijane niezależnie od siebie. Po pierwsze, dobro wspólne zasadza się w uznaniu godności człowieka; po wtóre, udaremnienie realizacji dobra wspólnego przez prawo i państwo jest podważeniem godności ludzkiej osoby; po trzecie, położenie akcentu na podmiotowość człowieka (jego godność) oraz przyporządkowanie instytucji społecznych dobru wspólnemu pozwala na odróżnienie tego, co jest celem działania państwa, a co środkiem do niego prowadzącym.

Argumenty te wymagają odpowiedzi. Co do pierwszego należy wskazać, że na władzy państwowej spoczywa obowiązek troski o dobro wspólne, które służy ochronie godności człowieka. Dobro wspólne jako ochrona osoby ludzkiej i wartości umożliwiających jej harmonijny rozwój konkretyzuje się w uznaniu uniwersalnej, niezmiennej i niezbywalnej ludzkiej godności. Trzeba zarazem zdawać sobie jednak sprawę z tego, że o dobrym lub złym funkcjonowaniu państwa decyduje to, czy umożliwia ono (lub nie) realizację wspólnego dobra ${ }^{28}$. Czy istnieje wobec tego dostateczne uzasadnienie dla twierdzenia, że władza występująca przeciwko wspólnemu dobru pozbawia samą siebie racji bytu? Problem ten ma niestety głębsze znaczenie praktyczne i mógłby zaistnieć realnie przede wszystkim wtedy, gdyby się okazało, że państwo nie umożliwia tego dobra przez swój system prawny. Jednoznaczne stanowisko w tej sprawie zajmuje M. Krąpiec, który twierdzi, że „Udaremnienie realizacji dobra wspólnego przez aktualną ekipę rządzącą pozbawia ją władzy, jako przewodniczki społecznej ku wspólnemu dobru, które jest i celem, i zarazem racją dostateczną bytu społecznego. Kto uderza w swą rację bytu, pozbawia się »bytu« w danym zakresie"29. Tak więc państwo istnieje dla dobra człowieka, w związku z czym również prawo jest dla dobra człowieka. Należy też przyjąć, że realizacja założeń dobra wspólnego (a zatem realnego dobra każdego człowieka i zarazem całej społeczności) nie może podważać godności ludzkiej osoby jako jego zasadniczego źródła ${ }^{30}$ i wymaga doboru przez państwo właściwych środków strukturalnych i instytucjonalnych. Dlatego państwo powinno patrzeć na człowieka zawsze jako cel, a nigdy środek do realizacji celu. Tym samym odpowiedzieliśmy na drugi i trzeci argument.

27 V. Possenti, Problem nowej cywilizacji chrześcijańskiej, „Ethos” 2000, nr 49-50, s. 119.

28 Zob. T. Ćwiertniak, Spoleczeństwo, państwo, dobro wspólne i polityka w ujęciu M.A. Krap$c a$, ,Rocznik Filozoficzny Ignatianum” 23, 2017, nr 2, s. 106.

29 M.A. Krąpiec, O ludzka polityke, Lublin 1998, s. 76.

30 Zdaniem M. Piechowiaka „konstytucyjne pojęcie godności jest istotnym, strukturalnym elementem pojęcia dobra wspólnego" — idem, Dobro wspólne jako fundament polskiego porządku konstytucyjnego, Warszawa 2012, s. 358. 


\section{Zamiast konkluzji}

Na zakończenie powtórzmy niektóre tezy (a może raczej problemy) tego wywodu. Po pierwsze, wymiarem podmiotowości człowieka jest jego godność jako wartość niezbywalna i niepowtarzalna. Przy takiej interpretacji godności za niedopuszczalne uznawane są zachowania prowadzące do instrumentalnego, czyli przedmiotowego, traktowania człowieka.

Po drugie, realizacja dobra wspólnego zależy od oparcia reguł funkcjonowania państwa na zasadach wynikających z odczytania natury człowieka (jego godności jako wymiaru podmiotowości człowieka). O ocenie administracji jako funkcji państwa polegającej na bezpośrednim realizowaniu dobra wspólnego decyduje stopień realizacji dobra wspólnego na gruncie określonego systemu prawnoustrojowego.

Po trzecie, z błędnym rozumieniem dobra wspólnego mamy do czynienia, gdy prawo i państwo stawiają siebie, a nie człowieka, za cel. Możemy mieć zatem do czynienia nie z dobrem wspólnym, ale ze wspólnymi interesami osób tworzących władzę.

Współczesne dyskusje o godności jako wymiarze podmiotowości człowieka i dobru wspólnym prowadzą też niejednokrotnie do wniosku, że wartości te poddawane są sprzecznym, by nie powiedzieć przeciwstawnym, dążeniom. Zasadnicze konflikty pojawiają się na tle przyczyn depersonalizacji współczesnego człowieka (pozbawienia go osobowej podmiotowości). Są one związane z cywilizacją techniczną, która choć powinna zostać zrównoważona przez cywilizację etyczną, to jednak na naszych oczach ulega coraz większej degradacji ${ }^{31}$. Przykładem depersonalizacji jest uprzedmiotowienie człowieka we wszystkich płaszczyznach życia, włącznie z manipulacją ideologiczną i polityczną ${ }^{32}$. W dobie obecnej opłacalności ekonomicznej urzeczywistnianej przez kapitał globalistyczny często dochodzi do zastępowania kategorii efektywności społecznej efektywnością ekonomiczną, obowiązującą na tak zwanym wolnym rynku ${ }^{33}$. W praktyce oznacza to podporządkowanie wszystkich priorytetów (w tym zdrowia i życia) regułom maksymalizacji stopy zysku.

Mimo teoretycznych refleksji na temat sprawiedliwego porządku społecznego w demokratycznym państwie w praktyce życia codziennego niestety stale mamy do czynienia z redukcjonizmem natury ludzkiej, opartym na paradygmacie

31 Por. T. Gadacz, Kryzys europejskiego społeczeństwa, http://www.pwt.wroc.pl/images/KFK/ 2017/Gadacz (dostęp: 3.11.2019).

32 Zob. J. Dębowski, Wobec zagrożeń współczesnej cywilizacji, http://www.kulturaswiecka. pl/node/908 (dostęp: 3.11.2019).

33 Zob. F. Piontek, B. Piontek, Transformacja a koncepcje rozwoju — skutki dla kapitału: ekonomicznego ludzkiego i przyrodniczego, „Nierówności Społeczne a Wzrost Gospodarczy. Problemy globalizacji i regionalizacji” 2006, nr 8, s. 35. 
ekonomii neoliberalnej. Nieskuteczność neoliberalnych recept przezwyciężania niespójności społeczno-ekonomicznej wiąże się z ignorowaniem strefy egzystencji ludzkiej w kontekście jej sprzężeń z uwarunkowaniami kulturowymi, społecznymi, etycznymi oraz przecenianiem mechanizmów rynkowych. Znalezienie punktu równowagi między konkurencyjnymi wartościami, to jest efektywnością ekonomiczną i sprawiedliwością społeczną, rozumianą jako równość dostępu do usług leczniczych, edukacyjnych itp., będzie ostatecznie zależała od tego, jakie znaczenie przyznamy każdej z tych wartości.

Konsekwencje cywilizacji technicznej dotyczą także współczesnych uniwersytetów i szkół wyższych, ponieważ zmieniają ich charakter i podstawową misję. Traktowanie uczelni jak przedsiębiorstw, nauki zaś jak przedsięwzięcia produkcyjnego $^{34}$ powoduje dominację celowości technicznej nad celowością humanistyczną. Mianowicie nie wystarczy sprowadzić myślenia wyłącznie do rozumu instrumentalnego (jak osiągać techniczne cele?) bez wskazania człowiekowi sensu życia, jego egzystencjalnego oparcia. Szczególnie ważną rolę mają tu do odegrania nauki humanistyczne, które otwierają człowieka na wartości wyższe, duchowe, etyczne. Jak pisał O. Marquard: „Modernizacja napędzana przez nauki eksperymentalne powoduje straty w środowisku życiowym, nauki humanistyczne natomiast straty te kompensują" 35 . Co więcej, owa kompensacja polega na tym, że nauki humanistyczne między innymi „uwrażliwiają człowieka i nadają mu orientację" 36 .

W pojęcie „kształcenia” wkładać można rzecz jasna rozmaite treści. Często wszak można spotkać się z opinią, że posiadanie umiejętności i kwalifikacji koniecznych do życia we współczesnej cywilizacji technicznej oznacza w danym środowisku umiejętność życia zgodnie z rangą człowieka, życia godnego i mądrego, cennego $\mathrm{z}$ określonego, moralnego punktu widzenia. W grę wchodzą tu niewątpliwie „umiejętności” intelektualne i prakseologiczne, na przykład w zdobywaniu kwalifikacji czy wyborze zawodu. Nie podważamy znaczenia tych umiejętności, kompetencji i kwalifikacji, ale wespół z nimi powinny wchodzić także „umiejętności” moralne: świadomość celów moralnych, aprobowana hierarchia wartości, motywacje i zasady postępowania. Teilhard de Chardin, przenosząc tę sprawę na szerszą płaszczyznę wiedzy w ogólności, pisał: „Moralność nie jest sprawą mniej ważną niż największe osiągnięcia mechaniki i biologii”37.

Jak kształcić? Punktem wyjścia i ośrodkiem takiej refleksji jest zachowanie podmiotowości człowieka. Kryzys ducha związany jest ściśle z prymatem warto-

34 Por. T. Gadacz, op. cit.

35 O. Marquard, O nieodzowności nauk humanistycznych, [w:] idem, Apologia przypadkowości, przeł. K. Krzemieniowa, Warszawa 1994, s. 108. Zob. także S. Czerniak, Jürgen Mittelstrass: Nauki humanistyczne w świetle idei jedności nauki, „Studia Filozoficzne i Interdyscyplinarne” 6, 2018, s. 29.

36 O. Marquard, O nieodzowności..., s. 108-109.

37 M. Michalik, Sfera uczuć, Warszawa 1975, s. 46. 
ści materialnych (hedonistycznych, użytecznościowych) nad wyższymi od nich wartościami etycznymi, intelektualnymi i estetycznymi ${ }^{38}$. Równie mało przydatna okazuje się nauka, która kieruje się kryterium prawdy, a nie dobrem człowieka. Przede wszystkim celem kształcenia nie może być jedynie przygotowywanie podmiotów na rynek pracy ani też — jak zauważa T. Gadacz — „ogranicza[nie] się do umiejętności porozumiewania się w języku angielskim i obsługiwania komputerów czy tabletów”39. Powinno ono „być poznaniem tego, co obchodzi nas jako ludzi, a nie tylko jako członków społeczeństwa przemysłowego" 40 . Umiejętność kształcenia jest największą sztuką, a doświadczenia historyczne i współczesne to potwierdzają. Adam Mickiewicz ubolewał w jednym z poematów, iż: „,młódź cierpi na tem, że nie ma szkół żyć z ludźmi i światem”"41. Oczywiście, im wyższa jest dojrzałość intelektualna i moralna człowieka, im większa jego wrażliwość i poczucie odpowiedzialności, tym większe jest dla niego znaczenie takiej refleksji.

\section{Bibliografia}

Apiecionek M., Idea personalizmu Emmanuela Mouniera, „Filozofia Chrześcijańska” 13, 2016.

Banaszak B., Zasady ustroju a prawa jednostki, „Rzeczpospolita” 14-15.06.1995.

Barth G., Pojęcie i rozwój personalizmu, http://hosting0800050.az.pl/personalizm/?p=142 (dostęp: 3.01.2019).

Blicharz J., Kategoria interesu publicznego jako przedmiot działania administracji publicznej, „Przegląd Prawa i Administracji” 40, 2004.

Blicharz J., Zacharko L., Globalizm a personalizm wobec administracji publicznej. Studium prawno-administracyjne, Wrocław 2019.

Boć J., Prawo administracyjne, Wrocław 2004.

Complak K., Normy pierwszego rozdziału Konstytucji RP, Wrocław 2007.

Complak K., Uwagi o godności człowieka oraz jej ochrona w świetle nowej konstytucji, „Przegląd Sejmowy" 1998, nr 5 (28).

Czekalski R., Personalistyczna pedagogika wychowawcza Jana Pawła II, „Warszawskie Studia Teologiczne" 21, 2008.

Czerniak S., Jürgen Mittelstrass: Nauki humanistyczne w świetle idei jedności nauki, „Studia Filozoficzne i Interdyscyplinarne" 6, 2018.

Ćwiertniak T., Społeczeństwo, państwo, dobro wspólne i polityka w ujęciu M.A. Krapca, „Rocznik Filozoficzny Ignatianum" 23, 2017, nr 2.

Dębowski J., Wobec zagrożeń współczesnej cywilizacji, http://www.kulturaswiecka.pl/node/908 (dostęp: 3.11.2019).

Drabarek A., Dlaczego personalizm nie jest i nie może stać się filozofia niedzielnego popoludnia, „Studia Philosophiae Christianae” 48, 2012, nr 4.

38 Por. T. Gadacz, op. cit.

39 T. Gadacz, Uniwersytet w czasach bezmyślności, wykład inauguracyjny, https://www.agh. edu.pl/info/article/uniwersytet-w-czasach-bezmyslnosci-wyklad-inauguracyjny/ (dostęp: 3.11.2019).

40 M. Horkheimer, Odpowiedzialność i studia, „Kronos” 2011, nr 2, s. 240.

${ }^{41}$ M. Michalik, op. cit., s. 45. 
Fundowicz S., Człowiek i administracja publiczna, [w:] Prawość i godność. Księga pamiatkowa w 70. rocznice urodzin Profesora Wojciecha Łaczkowskiego, red. S. Fundowicz, F. Rymarz,

A. Gomułowicz, Lublin 2003.

Gadacz T., Kryzys europejskiego społeczeństwa, http://www.pwt.wroc.pl/images/KFK/2017/Gadacz (dostęp: 3.11.2019).

Gadacz T., Uniwersytet w czasach bezmyślności, wykład inauguracyjny, https://www.agh.edu.pl/ info/article/uniwersytet-w-czasach-bezmyslnosci-wyklad-inauguracyjny/ (dostęp: 3.11.2019).

Horkheimer M., Odpowiedzialność i studia, „Kronos” 2011, nr 2.

Izdebski H., Kulesza M., Administracja publiczna, Warszawa 2004.

Kozłowski. R., Wokót problemu osoby. Definicje osoby w polskim personalizmie chrześcijańskim, „Stupskie Studia Filozoficzne” 2005, nr 5.

Krąpiec M.A., O ludzka politykę, Lublin 1998.

Laubier P. de, Myśl społeczna Kościoła katolickiego od Leona XIII do Jana Pawła II, Warszawa 1988.

Legowicz J., Zarys historii filozofii, Warszawa 1980.

Marquard O., O nieodzowności nauk humanistycznych, [w:] idem, Apologia przypadkowości, przeł. K. Krzemieniowa, Warszawa 1994.

Michalik M., Sfera uczuć, Warszawa 1975.

Piechowiak M., Dobro wspólne jako fundament polskiego porządku konstytucyjnego, Warszawa 2012.

Piontek E., Piontek B., Transformacja a koncepcje rozwoju — skutki dla kapitatu: ekonomicznego ludzkiego i przyrodniczego, „Nierówności Społeczne a Wzrost Gospodarczy. Problemy globalizacji i regionalizacji” 2006, $\mathrm{nr} 8$.

Possenti V., Problem nowej cywilizacji chrześcijańskiej, „Ethos” 2000, nr 49-50.

Stadniczenko S.L., Etos pracowników zawodów administracji publicznej, [w:] Między tradycja a przyszłościa w nance prawa administracyjnego. Księga jubileuszowa dedykowana Profesorowi Janowi Bociowi, red. J. Supernat, Wrocław 2009.

\title{
Human subjectivity and the mission of administration for the benefit of the common good (personal good) as values that cannot be ignored
}

\begin{abstract}
Summary
There are three serious arguments that the concepts of common good and dignity as a dimension of human subjectivity condition each other and cannot be developed separately. First, the common good is based on the recognition of human dignity. Secondly, the frustration of the realization of the common good by the state and the law undermines human dignity. Thirdly, the emphasis on human subjectivity (dignity) and the subordination of social institutions to the common good makes it possible to distinguish the objective of state action from the means instrumental with regard to this objective.
\end{abstract}

Keywords: dignity of (a) human being(s), public administration, country, the common good. 